\title{
EVALUASI TATA KELOLA TEKNOLOGI INFORMASI MENGGUNAKAN FRAMEWORK COBIT 4.1 PADA PERUSAHAAN DAERAH AIR MINUM SALATIGA
}

\author{
Kelvin Oktavianus Sunarto ${ }^{\circledR 1)}$, Yani Rahardja ${ }^{(2)}$, dan Melkior N. N. Sitokdana ${ }^{\left({ }^{3}\right)}$ \\ ${ }^{1,2,3}$ Sistem Informasi, Fakultas Teknologi Informasi, Universitas Kristen Satya Wacana \\ ${ }_{1,2,3}$ JL. Diponegoro no. 52-60, Salatiga, 50711 \\ E-mail : 682016010@student.uksw.edu ${ }^{1)}$, yani.rahardja@uksw.edu²), melkior.sitokdana@uksw.edu ${ }^{3)}$
}

\begin{abstract}
ABSTRAK
Perkembangan teknologi yang semakin cepat berdampak pada tingginya kebutuhan untuk menghasilkan informasi yang semakin cepat dan akurat, sehingga dibutuhkan adanya penerapan teknologi informasi yang memadai. Penerapan teknologi informasi dalam sebuah organisasi diharapkan mampu memberikan manfaat dalam mencapai tujuan organisasi secara lebih efektif dan efisien. Untuk menjamin efektivitas dan efisiensi penerapan teknologi informasi tersebut, maka diperlukan adanya sebuah pengawasan dan evaluasi terhadap penerapan tersebut. Penelitian ini akan melakukan evaluasi tata kelola teknologi informasi yang diterapkan di PDAM Salatiga dengan menggunakan kerangka kerja COBIT 4.1 pada domain Monitoring dan Evaluasi (ME). Hasil penelitian menunjukkan bahwa secara umum perusahaan telah mencapai tingkat kematangan 2,5 yang berarti sudah mencapai tingkat repeated but intuitive dan belum mencapai tingkat 3 (defined level). Untuk mencapai tingkat kematangan yang lebih tinggi, maka PDAM Salatiga diharapkan mampu meningkatkan nilai di ME1 dan ME2.
\end{abstract}

Kata Kunci: COBIT 4.1, Monitoring Dan Evaluasi, Tata Kelola, Teknologi Informasi, Kualitatif

\section{PENDAHULUAN}

Perkembangan teknologi yang semakin cepat telah diimbangi dengan pemanfaatannya dari waktu ke waktu, sehingga kecepatan dan keakuratan informasi menjadi hal utama yang menjadi prioritas bagi keberlangsungan usaha (Chandra, 2018). Salah satu teknologi yang diterapkan di banyak perusahaan adalah teknologi informasi, yang jika dikelola dengan baik akan menjamin efisiensi dan efektivitas pencapaian tujuan organisasi (Marzuki, dkk, 2018). Salah satu organisasi yang menerapkan teknologi informasi untuk menjamin tercapainya tujuan organisasi adalah Perusahaan Daerah Air Minum (PDAM) Salatiga. Sebagai Badan Usaha Milik Daerah (BUMD) yang dirintis sejak zaman kolonial oleh pemerintah Belanda sejak tahun 1921 dengan nama Dinas Air Minum, secara resmi berganti nama menjadi PDAM Salatiga pada tahun 1968 melalui Surat Keputusan Walikota Madya Kepala Daerah Tingkat II Salatiga nomor 8.a/Kepada/Um-Pan. Lebih lanjut, Peraturan Daerah Kotamadya Kepala Daerah Tingkat II Salatiga nomor 20 tahun 1971 menetapkan peran PDAM Salatiga sebagai lembaga pemerintah untuk memenuhi kebutuhan air bersih kota Salatiga.

Berdasarkan observasi awal yang dilakukan, diperoleh informasi bahwa sampai saat ini PDAM Salatiga telah menggunakan sistem teknologi informasi untuk tujuan administrasi dan pelayanan yang dibuat oleh lembaga di luar entitas (outsourcing), sehingga penggunaan dan pemanfaatan teknologi informasi belum dilakukan secara menyeluruh di dalam perusahaan daerah ini maka diperlukan tindakan monitoring dan evaluasi sistem informasi yang telah digunakan agar ke depannya dapat menerapkan teknologi informasi secara keseluruhan. Salah satu instrumen yang dapat digunakan untuk melakukan monitoring dan evaluasi adalah COBIT 4.1., yang tepat digunakan karena telah menjadi standar komprehensif yang membantu perusahaan dalam mencapai tujuan dan menghasilkan nilai melalui penilaian tata kelola perusahaan dan pengelolaan teknologi informasi yang efektif.

Penelitian ini menggunakan COBIT 4.1 karena selain objek observasinya terbatas pada departemen administrasi dan umum, waktu yang dibutuhkan akan lebih singkat daripada menggunakan COBIT 5 yang membutuhkan lebih banyak waktu karena penggunaannya yang komprehensif (Governance, 2018). Oleh karena itu, digunakan dalam penelitian ini untuk menyesuaikan luas observasi sehingga penelitian ini bertujuan untuk menambah bukti empiris penggunaan dimensi monitoring dan evaluasi untuk digunakan sebagai alat analisis penerapan dan pengelolaan sistem informasi khususnya pada lembaga pemerintah. Selain itu, penelitian ini juga bertujuan untuk memberikan saran perbaikan terhadap sistem informasi yang sudah ada dan pemberian rekomendasi untuk menggunakan teknologi sistem informasi di semua departemen yang ada di dalam PDAM Salatiga.

Terdapat beberapa penelitian terdahulu yang berkaitan dengan penelitian ini, yaitu penelitian oleh (Lesmono \& Erca, 2018) yang berjudul "Tata Kelola Teknologi Informasi dengan Metode COBIT 4.1 pada PT 
IMI yang menyatakan bahwa pihak manajemen masih belum memahami pentingnya investasi pada bidang teknologi informasi, manajemen risiko yang belum dilakukan dengan baik dan kemampuan Sumber Daya Manusia (SDM) yang masih kurang baik. Secara keseluruhan, kematangan tata kelola TI berada pada tingkat defined yang artinya seluruh proses yang menyangkut kinerja TI di PT IMI telah didokumentasikan dan dikomunikasikan dengan baik namun belum dilakukan secara menyeluruh sehingga masih memungkinkan terjadinya penyimpangan.

Penelitian berikutnya yang berkaitan dengan penelitian ini adalah evaluasi tata kelola audit sistem informasi dengan menggunakan COBIT 4.1 untuk evaluasi manajemen teknologi informasi di PT Yamaha Manufacturing (Mulyanto, 2018). Penelitian tersebut menyatakan menyatakan bahwa pada domain monitoring dan evaluasi perusahaan berada pada level di bawah ratarata dengan nilai 1,25 sehingga masih perlu melakukan perbaikan untuk meningkatkan nilai maturity level. (Rahmanisa, 2018) melakukan analis pengawasan dan evaluasi tata kelola teknologi informasi pada PT Angkasa Pura 1 pada domain ME dan mendapatkan hasil bahwa tingkat kematangan (maturity level) pengawasan dan evaluasi teknologi informasi berada tingkat 2 sedangkan tingkat harapan perusahaan berada pada tingkat 4 sehingga diperlukan tindak lanjut untuk memperbaiki tindakan pengawasan dan evaluasi agar mampu mencapai tingkat yang diharapkan.

Lebih lanjut, domain ME pada kerangka kerja COBIT 4.1 juga digunakan oleh (Pambudi, dkk, 2018) pada tata kelola sistem informasi akademik STMIK Bumigora Mataram dan pada tata kelola teknologi informasi Dinas Komunikasi dan Informatika (DISKOMINFO) kota Probolinggo. Hasil dari penelitian-penelitian tersebut menunjukkan bahwa nilai maturity level masih berada di tingkat yang rendah (tingkat 2 untuk STMIK Bumigora Mataram dan 1,25 untuk DISKOMINFO Probolinggo) sehingga masih diperlukan perbaikan yang perlu dilakukan dalam hal pengawasan dan evaluasi dari sistem informasi yang digunakan. Berdasarkan paparan di atas, dapat disimpulkan bahwa penggunaan kerangka kerja COBIT 4.1 domain ME telah memadai untuk digunakan dalam penilaian tata kelola sistem informasi khususnya bagian pengawasan dan evaluasi (Imami, dkk, 2018).

Tata kelola didefinisikan sebagai suatu sistem pengendalian internal perusahaan yang bertujuan untuk mengelola risiko yang signifikan guna memenuhi tujuan bisnis melalui pengamanan aset dan meningkatkan nilai bagi stakeholder dalam jangka panjang (Effendi, 2016). Jika dikaitkan dengan teknologi informasi, maka dapat dimaknai bahwa tata kelola teknologi informasi merupakan pengendalian internal yang dilakukan oleh perusahaan dalam hal pemanfaatan teknologi informasi sehingga mampu membantu perusahaan dalam mencapai tujuan organisasi melalui penggunaan teknologi tersebut yang dapat meningkatkan nilai perusahaan sehingga mampu meningkatkan nilai jangka panjang bagi stakeholder (Hakim, 2017) COBIT 4.1 menyediakan kerangka kerja IT Governance dan control objectives yang rinci bagi manajemen, pemilik proses bisnis, pemakai dan auditor, karena mengelola teknologi informasi secara holistic sehingga nilai yang diberikan oleh teknologi informasi dapat tercapai optimal dengan memperhatikan segala aspek tata kelola teknologi informasi mulai dari sisi people, skills, competencies, services, infrastructure, dan applications yang merupakan bagian dari enable suatu tata kelola teknologi informasi (Indah, 2018).

\section{RUANG LINGKUP}

Dalam penelitian ini permasalahan mencakup:

1. Penerapan sistem informasi pada Perusahaan Daerah Air Minum (PDAM) Salatiga yang masih terbatas pada tujuan administrasi dan pelayanan saja atau dengan kata lain belum diterapkan secara menyeluruh untuk keseluruhan organisasi. Oleh karena itu, perlu dilakukan aktivitas pengawasan dan evaluasi untuk menilai kematangan penerapan yang nantinya akan diterapkan juga untuk keseluruhan organisasi.

2. Batasan dalam penelitian ini adalah domain yang digunakan dari kerangka kerja COBIT 4.1 hanya Monitoring dan Evaluasi (ME) pada penerapan sistem informasi di divisi administrasi dan pelayanan

3. Rencana hasil yang didapatkan dari penelitian ini adalah menghasilkan rekomendasi atas hasil analis terhadap penerapan sistem informasi yang sudah ada dan diterapkan.

\section{BAHAN DAN METODE}

Penelitian ini merupakan penelitian deskriptif kualitatif sehingga hasil observasi akan digunakan sebagai bahan untuk kemudian dianalisis dengan menggunakan kerangka kerja yang sudah ditetapkan sebelumnya. Peneliti mengumpulkan data dan informasi yang diperoleh dari hasil wawancara dengan pihak-pihak terkait yang ada di dalam PDAM sebagai objek penelitian.

COBIT 4.1 merupakan standar komprehensif yang membantu perusahaan dalam mencapai tujuan dan menghasilkan nilai melalui tata kelola dan manajemen teknologi informasi yang efektif. COBIT 4.1 merupakan suatu alat komprehensif untuk menjembatani kebutuhan perusahaan untuk menilai risiko bisnis, kebutuhan pengendalian sehingga dapat membantu perusahaan dalam mencapai tujuannya (Putra \& Rahayu, 2020). Adapun area atau domain yang mampu diakomodir oleh kerangka kerja tersebut adalah Plan and Organise (PO), Acquire and Implement (AI), Deliver and Support (DS) dan Monitor and Evaluate (ME). Lebih lanjut, domaindomain yang ada pada kerangka kerja tersebut memiliki keterkaitan yang dapat dilihat pada Gambar 1. 


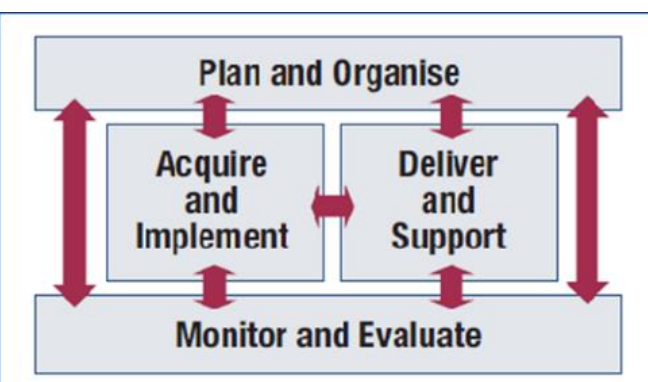

Gambar 1. Kerangka Kerja COBIT 4.1

Domain Plan and Organise (PO) merupakan domain yang meliputi taktik dan strategi, dan berfokus pada bagaimana teknologi informasi berkontribusi dalam mencapai tujuan bisnis. Domain ini merupakan area di mana realisasi dari sebuah visi strategis perlu direncanakan, dikomunikasikan dan dikelola untuk berbagai perspektif yang berbeda. Perencanaan dan pengorganisasian yang baik serta infrastruktur teknologi harus ditempatkan secara sesuai.

Domain Acquire and Implement (AI) merupakan domain yang membantu pihak manajemen untuk mengidentifikasi, mengembangkan, merealisasikan dan mengimplementasikan strategi teknologi informasi dengan mengintegrasikannya dengan proses bisnis. Domain ini juga membantu untuk memberikan solusi terhadap teknologi yang telah diimplementasikan sehingga dapat diketahui kelemahan dan hambatan dalam pengimplementasian untuk dijadikan panduan dalam melakukan pemeliharaan sistem yang ada. Dengan dilakukannya langkah implementasi dan pengumpulan solusi maka siklus hidup organisasi dapat terus berlangsung.

Domain Deliver and Support (DS) merupakan domain yang berfokus pada penyajian kebutuhan layanan, penyajian layanan, manajemen kontinuitas dari keamanan, pendukung layanan untuk user, serta pengelolaan data dan operasional. Domain ini memampukan organisasi untuk memperoleh berbagai dukungan yang relevan dengan implementasi TI sehingga meningkatkan efektifitas dan efisiensi tata kelola organisasi.

Domain Monitor and Evaluate (ME) merupakan domain yang membahas tentang penilaian secara teratur untuk kualitas dan pemenuhan dengan pengendalian kebutuhan. Domain ini menunjukkan perlunya pengawasan manajemen atas proses pengendalian dalam organisasi serta penilaian independen yang dilakukan baik oleh auditor internal maupun eksternal berdasarkan segala informasi yang relevan dari berbagai sumber. Pengukuran tingkat kematangan pada domain monitoring dan evaluasi memungkinkan para manajer mengetahui bagaimana pengelolaan dan proses implementasi teknologi informasi di organisasi sehingga dapat diketahui tingkat kematangan dari pengelolaan implementasi tersebut.

\subsection{Metode Penelitian}

Metodologi penelitian merupakan cara yang digunakan untuk mendukung proses penelitian agar lebih terstruktur dan sistematis. Penelitian ini merupakan penelitian kualitatif yang bertujuan untuk mendeskripsikan keadaan sesungguhnya yang ada di objek observasi, yaitu Perusahaan Daerah Air Minum (PDAM) Salatiga, dengan tahapan penelitian yang dapat dilihat pada Gambar 2.

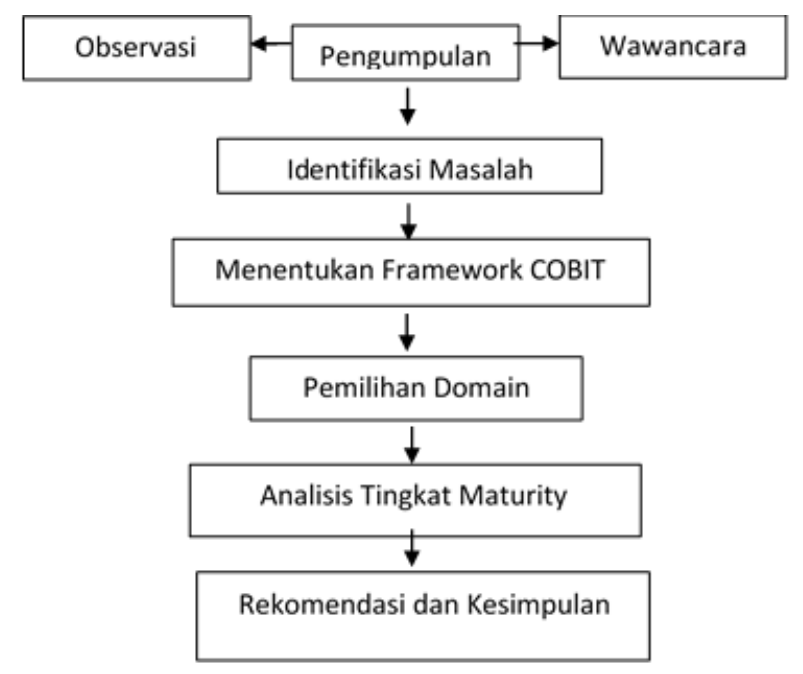

Gambar 2. Tahapan Penelitian

Pengumpulan data dan informasi dilakukan dengan cara melakukan wawancara secara mendalam (in-depth interview) dengan Bapak Anton selaku kepala bagian administrasi dan umum dan observasi di objek pengamatan selama satu bulan. Adapun pengumpulan data dilakukan pada saat melakukan kunjungan sebanyak dua kali dalam satu minggu, dengan tujuan agar tetap dapat memperoleh data dan informasi yang relevan namun tidak mengganggu aktivitas operasional objek observasi. Setelah itu, dilakukan identifikasi masalah berdasarkan data dan informasi yang sudah diperoleh. Identifikasi masalah dilakukan agar dapat menentukan langkah analis yang tepat untuk memberikan saran perbaikan bagi objek penelitian.

Langkah berikutnya yang dilakukan adalah menentukan domain COBIT 4.1 yang tepat untuk menganalisa masalah, melakukan penilaian dan menentukan saran perbaikan. Berdasarkan kondisi objek observasi yang sejauh ini menggunakan perangkat lunak yang dibuat oleh lembaga di luar objek observasi (outsourcing) dan digunakan hanya di departemen administrasi dan pelayanan. Oleh karena itu, perlu dilakukan pengawasan dan evaluasi untuk menentukan apakah ada perbaikan yang harus diperbaiki sehingga dapat menggunakan sistem informasi yang lebih baik dan dapat digunakan di semua departemen. Domain yang digunakan untuk melakukan penilaian itu adalah domain Monitoring dan Evaluasi (ME). 
Setelah itu, tahap berikutnya yang dilakukan adalah menentukan tingkat maturity level dan melakukan analisis kesenjangan untuk mengetahui gap antara level maturity saat ini dengan target yang ingin dicapai. Instrumen yang digunakan adalah indikator pengukuran yang ada pada ME1, ME2, ME3 dan ME4. ME 1 bertujuan untuk mengetahui sejauh mana pengawasan terhadap permasalahan TI, mengidentifikasi serta melakukan tindakan perbaikan. ME 2 bertujuan untuk mengetahui sejauh mana sudah memantau dan mengevaluasi efisiensi dan efektivitas terhadap TI. ME 3 bertujuan untuk mengetahui sejauh mana perusahaan meninjau dan menyesuaikan kebijakan TI sudah berjalan sesuai hukum yang berlaku secara lokal maupun nasional dan ME4 bertujuan untuk mengetahui sejauh mana sudah mengelola investasi teknologi perusahaan, Tahap terakhir adalah melakukan penarikan kesimpulan dan pemberian saran untuk perbaikan di masa yang akan datang.

\section{PEMBAHASAN}

Berdasarkan in-depth interview dan observasi yang dilakukan, maka diperoleh data berupa hasil pengisian kuesioner yang diisi oleh Bapak Anton selaku kepala bagian administrasi dan umum. Data kuesioner tersebut diolah sehingga terbagi menjadi empat skor, yaitu ME1 yang menunjukkan aktivitas monitoring dan evaluasi terhadap kinerja teknologi informasi yang digunakan, ME2 yang menunjukkan aktivitas monitoring dan evaluasi terhadap kinerja pengendalian internal penggunaan teknologi informasi, ME3 yang menunjukkan aktivitas penilaian dan penyesuaian terhadap teknologi dan informasi yang digunakan dan ME4 yang menunjukkan tata kelola perusahaan terhadap penggunaan teknologi informasi yang ada. Secara lebih rinci, nilai dari masing-masing kategori skor dapat dilihat pada tabel 1 .

Tabel 1. Skor Domain ME

\begin{tabular}{|c|c|c|c|c|c|}
\hline Kategori Domain & ME1 & ME2 & ME3 & ME4 & Rata-rata \\
\hline Indeks Kuesioner & 2 & 2 & 3 & 3 & 2,5 \\
\hline Maturity Level & 2 & 2 & 3 & 3 & 2,5 \\
\hline
\end{tabular}

Control objective pada ME1 digunakan untuk memastikan bahwa pemanfaatan teknologi informasi dapat memberikan kontribusi yang sesuai dengan arahan dan kebijakan yang sudah ditetapkan dengan kebutuhan bisnis yang ada. Berdasarkan skor ME1 pada tabel 2 menunjukkan bahwa perusahaan masih belum melakukan pelaporan ketercapaian tujuan yang sudah direncanakan, penggunaan sumber daya dalam mencapai tujuan dan pemenuhan kinerja. Perusahaan juga masih belum mengintegrasikan kerangka kerja dengan proses bisnis yang berjalan, pengawasan terhadap permasalahan dari penggunaan teknologi informasi dan juga melakukan tindakan identifikasi masalah dan perbaikan dari pemantauan kinerja, penilaian dan pelaporan, sehingga terdapat beberapa rekomendasi yang ada pada tabel 3.

Tabel 2. Skor Domain ME 1

\begin{tabular}{|c|c|c|}
\hline No. & Proses & Kondisi Saat Ini \\
\hline \multirow[t]{5}{*}{1} & \multirow[t]{5}{*}{ ME1 } & $\begin{array}{l}\text { Belum ada pelaporan ketercapaian tujuan } \\
\text { yang direncanakan secara rutin }\end{array}$ \\
\hline & & $\begin{array}{l}\text { Belum ada pelaporan penggunaan sumber } \\
\text { daya dalam mencapai tujuan dan pemenuhan } \\
\text { kinerja secara rutin }\end{array}$ \\
\hline & & $\begin{array}{l}\text { Belum mengintegrasikan kerangka kerja } \\
\text { dengan proses bisnis secara optimal }\end{array}$ \\
\hline & & $\begin{array}{l}\text { Belum melakukan pengawasan terhadap } \\
\text { perma salahan dari penggunaan teknologi } \\
\text { informasi secara rutin }\end{array}$ \\
\hline & & $\begin{array}{l}\text { Belum melakukan tindak identifikasi masalah } \\
\text { dan perbaikan dari kegiatan pemantauan } \\
\text { kinerja, penilaian dan pelaporan secara } \\
\text { maksimal }\end{array}$ \\
\hline
\end{tabular}

Tabel 3. Rekomendasi Domain ME 1

\begin{tabular}{|c|c|c|}
\hline No. & Proses & Rekomendasi \\
\hline \multirow[t]{5}{*}{1} & \multirow[t]{5}{*}{ ME1 } & $\begin{array}{l}\text { Meningkatkan intensitas pelaporan agar } \\
\text { semakin rutin }\end{array}$ \\
\hline & & $\begin{array}{llll}\begin{array}{l}\text { Meningkatkan } \\
\text { semakin rutin }\end{array} & \text { intensitas } & \text { pelaporan } & \text { agar } \\
\end{array}$ \\
\hline & & $\begin{array}{l}\text { Mengoptimalkan integrasi antara kerangka } \\
\text { kerja dengan proses bisnis }\end{array}$ \\
\hline & & $\begin{array}{l}\text { Meningkatkan intensitas pengawasan terhadap } \\
\text { permasalahan dari penggunaan teknologi } \\
\text { informasi }\end{array}$ \\
\hline & & $\begin{array}{l}\text { Melakukan identifikasi terhadap potensi } \\
\text { masalah yang dapat timbul beserta langkah } \\
\text { pencegahan dan perbaikannya, serta } \\
\text { melakukan tindakan penilaian dan pelaporan } \\
\text { secara maksimal }\end{array}$ \\
\hline
\end{tabular}

Control objective pada ME2 digunakan untuk menentukan apakah suatu pengendalian internal sudah dilakukan secara efektif dan sesuai dengan regulasi yang ada. Proses ini meliputi pengawasan dan pelaporan pengendalian, hasil dari pengujian dan review dari pihak ketiga. Kategori ini berfokus pada proses pengawasan pengendalian internal yang dilakukan pada kegiatan yang berhubungan dengan implementasi teknologi informasi dan mengidentifikasi hal-hal yang perlu diperbaiki. Sama seperti ME1, ME2 juga memiliki skor 2 seperti yang terlihat pada tabel 4 karena perusahaan masih belum melakukan aktivitas pemantauan dan evaluasi yang maksimal terhadap efisiensi dan efektifitas dari pengendalian teknologi informasi untuk manajerial internal. Perusahaan juga masih belum melakukan pemantauan secara maksimal dan peningkatan kontrol terhadap teknologi informasi yang berjalan untuk memenuhi tujuan organisasi meskipun sudah melakukan pelaporan masalah yang ditemukan kepada pihak yang bertanggung jawab, sehingga terdapat beberapa rekomendasi yang ada pada tabel 5 
Tabel 4. Skor Domain ME 2

\begin{tabular}{|c|c|l|}
\hline No. & Proses & \multicolumn{1}{|c|}{ Kondisi Saat Ini } \\
\hline 2 & ME2 & $\begin{array}{l}\text { Belum melakukan tindak aktivitas } \\
\text { pemantauan dan evaluasi yang maksimal } \\
\text { terhadap efisiensi dan efektifitas pengendalian } \\
\text { teknologi informasi untuk pihak manajerial } \\
\text { internal }\end{array}$ \\
\cline { 3 - 4 } & $\begin{array}{l}\text { Belum melakukan pemantauan secara } \\
\text { maksimal dan peningkatan kontrol terhadap } \\
\text { penggunaan teknologi informasi yang ada } \\
\text { untuk memenuhi tujuan organisasi meskipun } \\
\text { sudah melakukan pelaporan masalah yang } \\
\text { ditemukan kepada pihak yang bertanggung } \\
\text { jawab }\end{array}$ \\
\hline
\end{tabular}

Tabel 5. Rekomendasi Domain ME 3

\begin{tabular}{|c|c|l|}
\hline No. & Proses & \multicolumn{1}{|c|}{ Rekomendasi } \\
\hline 2 & ME2 & $\begin{array}{l}\text { Melakukan aktivitas pemantauan dan evaluasi } \\
\text { yang maksimal terhadap efisiensi dan } \\
\text { efektifitas pengendalian teknologi informasi } \\
\text { untuk pihak manajerial internal }\end{array}$ \\
\cline { 3 - 4 } & & $\begin{array}{l}\text { Melakukan pemantauan secara maksimal dan } \\
\text { peningkatan kontrol terhadap penggunaan }\end{array}$ \\
& teknologi informasi yang ada untuk \\
memenuhi tujuan organisasi. \\
\end{tabular}

Control objective pada ME3 digunakan untuk mengukur tingkat kesesuaian perangkat lunak yang digunakan pada bagian administrasi dan umum dengan peraturan yang berlaku. Kategori ini berfokus pada proses mengidentifikasi seluruh regulasi yang diaplikasikan dan hubungan tingkat kesesuaian teknologi informasi dengan kemampuan prosedur untuk mengurangi risiko tidak sesuai dengan peraturan yang ada. Seperti yang dapat dilihat pada tabel 6, ME3 memiliki skor 3 sehingga dapat disimpulkan bahwa PDAM Salatiga telah mengetahui adanya berbagai hal yang dapat menjadi sumber permasalahan khususnya ketidaksesuaian dengan peraturan yang ada dan telah memiliki solusi atas permasalahan tersebut serta telah memiliki serangkaian prosedur standar dan struktur yang jelas untuk mengatasi permasalahan tersebut, sehingga terdapat beberapa rekomendasi yang ada pada tabel 7 .

Tabel 6. Skor Domain ME 3

\begin{tabular}{|c|c|c|}
\hline No. & Proses & Kondisi Saat Ini \\
\hline \multirow[t]{3}{*}{3} & \multirow[t]{3}{*}{ ME3 } & $\begin{array}{l}\text { Mengetahui adanya berbagai hal yang } \\
\text { dapat menjadi sumber permasalahan } \\
\text { khususnya ketidaksesuaian dengan } \\
\text { peraturan yang ada. }\end{array}$ \\
\hline & & $\begin{array}{l}\text { Memiliki solusi atas segala } \\
\text { permasalahan yang muncul }\end{array}$ \\
\hline & & $\begin{array}{l}\text { Memiliki serangkaian prosedur struktur } \\
\text { yang jelas untuk mengatasi } \\
\text { permasalahan yang muncul }\end{array}$ \\
\hline
\end{tabular}

Tabel 7. Rekomendasi Domain ME3

\begin{tabular}{|c|c|l|}
\hline No. & Proses & \multicolumn{1}{|c|}{ Rekomendasi } \\
\hline 3 & ME3 & $\begin{array}{l}\text { Pertahankan kondisi saat ini } \\
\text { Tingkatkan intensitas pengawasan dan } \\
\text { evaluasi }\end{array}$ \\
\cline { 3 - 3 } & & $\begin{array}{l}\text { Pertahankan kondisi saat ini } \\
\text { terhadap prosedur standar yang sudah } \\
\text { ada }\end{array}$ \\
\hline
\end{tabular}

Control objective pada ME4 digunakan untuk menjamin bahwa investasi pada sistem informasi selaras dengan tujuan perusahaan baik struktur organisasi, proses, kepemimpinan, peran dan tanggung jawab PDAM Salatiga. Sama seperti ME3, ME4 juga memiliki skor 3 seperti yang terlihat pada tabel 8 sehingga dapat disimpulkan bahwa organisasi telah menyadari adanya perkembangan teknologi informasi dan telah memahami bahwa dengan menggunakan teknologi informasi dapat membantu pelayanan di PDAM Salatiga, sehingga terdapat beberapa rekomendasi yang dapat dilihat pada tabel 9.

Tabel 8. Skor Domain ME 4

\begin{tabular}{|c|c|l|}
\hline No. & Proses & \multicolumn{1}{|c|}{ Kondisi Saat Ini } \\
\hline 4 & ME4 & $\begin{array}{l}\text { Telah menyadari adanya perkembangan } \\
\text { teknologi informasi }\end{array}$ \\
\cline { 3 - 4 } & & $\begin{array}{l}\text { Telah memahami manfaat penggunaan } \\
\text { teknologi informasi untuk peningkatan } \\
\text { kinerja operasional }\end{array}$ \\
\hline
\end{tabular}

Tabel 9. Rekomendasi Domain ME 4

\begin{tabular}{|c|c|l|}
\hline No. & Proses & \multicolumn{1}{c|}{ Rekomendasi } \\
\hline 4 & ME4 & $\begin{array}{l}\text { Pertahankan kondisi saat ini } \\
\text { Tingkatkan wawasan mengenai teknologi } \\
\text { yang lebih baru }\end{array}$ \\
\cline { 3 - 4 } & & $\begin{array}{l}\text { Pertahankan kondisi saat ini } \\
\text { Lakukan evaluasi secara berkala terhadap } \\
\text { sistem yang sudah ada dan kemungkinan } \\
\text { untuk menggunakan sistem yang lebih } \\
\text { baru }\end{array}$ \\
\hline
\end{tabular}

\section{KESIMPULAN}

Berdasarkan analisis yang telah dilakukan terhadap domain ME pada objek observasi PDAM Salatiga, dapat disimpulkan bahwa secara umum PDAM Salatiga telah memiliki tata kelola teknologi informasi yang baik, meskipun tingkat maturity level domain ME masih berada pada level 2 yaitu repeatable but intuitive. Kategori ME3 dan ME4 perlu untuk dipertahankan namun ME1 dan ME2 perlu untuk ditingkatkan. Lebih lanjut, setelah melakukan langkah perbaikan kategori ME1 dan ME2 maka diharapkan PDAM Salatiga dapat menerapkan tata kelola yang baik bagi kegiatan monitoring dan evaluasi sehingga dapat menerapkan sistem teknologi informasi yang tetap untuk departemen umum dan pelayanan dan ke depannya mampu menggunakan sistem teknologi informasi untuk semua departemen. 


\section{SARAN}

Saran yang dapat diberikan kepada PDAM Salatiga adalah sesegera mungkin melalukan perubahan serangkaian prosedur agar dapat dilakukan pelaporan ketercapaian tujuan yang sudah direncanakan, penggunaan sumber daya dalam mencapai tujuan dan pemenuhan kinerja. Perusahaan juga disarankan untuk mengintegrasikan kerangka kerja dengan proses bisnis yang berjalan, pengawasan terhadap permasalahan dari penggunaan teknologi informasi dan juga melakukan tindakan identifikasi masalah dan perbaikan dari pemantauan kinerja, penilaian dan pelaporan.

Lebih lanjut, perusahaan disarankan untuk melakukan aktivitas pemantauan dan evaluasi yang maksimal terhadap efisiensi dan efektifitas dari pengendalian teknologi informasi untuk manajerial internal. Pemantauan secara maksimal dan peningkatan kontrol terhadap teknologi informasi yang berjalan juga perlu untuk dilakukan agar dapat memenuhi tujuan organisasi untuk mendukung kebijakan perusahaan melakukan pelaporan masalah yang ditemukan kepada pihak yang bertanggung jawab. Penelitian berikutnya dapat menggunakan objek yang sama namun menggunakan domain lainnya, atau melakukan perbandingan antara PDAM Salatiga dengan perusahaan swasta. Lebih lanjut, penelitian berikutnya juga dapat menggunakan kerangka kerja COBIT 5 sehingga pembahasan menjadi lebih komprehensif.

\section{DAFTAR PUSTAKA}

Chandra, A. (2018). Penerapan Tata Kelola Teknologi Infomasi menggunakan Framework COBIT 4-1 dengan Model Maturity Level Studi Kasus di PT. Telkom Witel Yogyakarta [Universitas Islam Indonesia].

https://dspace.uii.ac.id/bitstream/handle/123456789 /7020/setelah pendadaran tesis Adityawan Chandra 2018-04-19.pdf?sequence $=1 \&$ is Allowed $=\mathrm{y}$

Effendi, A. (2016). The Power of Good Corporate Governance. Salemba Empat.

Governance, I. (2018). COBIT 4.1 vs COBIT 5. 2018. http://itgovernance.com/changes in cobit5.pdf

Hakim, M. M. (2017). IT Audit of IT Service Provider Using COBIT 4.1 Framework: Case Study at PT.
XYZ. Fountain of Informatics Journal, 2(2), 28. https://doi.org/10.21111/fij.v2i2.1236

Imami, L., Wahyu, S., \& Mursityo, Y. T. (2018). Audit Tata Kelola Teknologi Informasi pada Dinas Komunikasi dan Informatika (DISKOMINFO) Kota Probolinggo Menggunakan Kerangka Kerja COBIT 4.1 Domain Plan and Organize dan Acquire and Implement. Jurnal Pengembangan Teknologi Informasi Dan Ilmu Komputer, 2(9), 3425-3432.

Indah, H. (2018). Framework COBIT 4.1 untuk Audit Sistem Informasi pada Perwakilan Badan Kependudukan dan Keluarga Berencana Nasional (BKKBN) Provinsi ABCD. Sekolah Tinggi Manajemen Informatika dan Komputer.

Lesmono, I. D., \& Erca, D. (2018). Tata Kelola Teknologi Informasi Dengan Metode COBIT 4.1 (Studi Kasus: PT.IMI). Jurnal Kajian Ilmiah, 18(1). https://doi.org/10.31599/jki.v18i1.198

Marzuki, K., Setyanto, A., \& Nasiri, A. (2018). Audit Tata Kelola Teknologi Informasi Menggunakan COBIT 4.1 Domain Monitoring dan Evaluasi pada Perguruan Tinggi Swasta. Seminar Nasional Sistem Informasi Dan Teknologi Informasi.

Mulyanto, A. (2018). Audit Sistem Informasi dengan Menggunakan COBIT 4.1 untuk Evaluasi Manajemen Teknologi Informasi. Seminar Nasional Teknologi Dan Bisnis.

Pambudi, R., Suprapto, \& Mursityo, Y. T. (2018). Evaluasi Tata Kelola Teknologi Informasi pada Dinas Komunikasi dan Informatika (DISKOMINFO) Menggunakan Kerangka Kerja COBIT 4.1 Domain Deliver and Support dan Monitor and Evaluate. Jurnal Pengembangan Teknologi Informasi Dan Ilmu Komputer, 2(11), 3425-3432.

Putra, D. G., \& Rahayu, R. (2020). Peranan Implementasi Tata Kelola Teknologi Informasi (IT Governance) sebagai Faktor Penting dalam Meningkatkan Kinerja Perusahaan. Jurnal Inovasi Pendidikan Ekonomi (JIPE), 10(1), 01. https://doi.org/10.24036/011077110

Rahmanisa, A. (2018). Analisis Pengawasan dan Evaluasi Tata Kelola Teknologi Informasi PT Angkasa Pura I Semarang dengan Framework COBIT 4.1. Universitas Dian Nuswantoro. 